\title{
Corruption and the Nigerian Youth: Implication for Development
}

\author{
OLUWALEYE, Janet Monisola \\ Department of Political Science \\ Ekiti State University, Ado -Ekiti, Nigeria
}

\begin{abstract}
Corruption is an anathema to development. Its effects cut across all spheres of life. Despite her natural and human resource endowments, corruption has been a major factor obstructing Nigeria's sustainable development. Considering the manifestations of corruption among Nigerian students in general, the study examines the impacts of corruption among students of Nigerian tertiary institutions on the country's sustainable socio-economic and political development. Using both primary and secondary data, the study reveals the diverse manifestations of corruption among the students of Nigerian tertiary institutions. These include but are not limited to examination malpractices, procurement of fake certificates, betting, internet scam etc.ng others which are wrong signals to sustainable development of the country. The study recommends that there is need for re-orientation for hard work, integrity and transparency among the Nigerian students to enhance sustainable development. Task force should be put in place to combat corruption among the Nigerian students.
\end{abstract}

KeyWords: Corruption, Development, Youths, Transparency

\section{INTRODUCTION}

The rate of corruption in Nigeria of recent is alarming. The scourge cut across all segments of life, among all categories of people and through every stage of development. Corruption has eating deep into the fabric of the nation. Nigeria, one of the most populous countries in Africa has been ranked high in most survey carried out by Transparency International and other organizations that monitor corrupt practices. According to Uzochukwu [2016], in 2000, Nigeria ranked the most corrupt country, in 2001, 2002 and 2003, the country maintained the $2^{\text {nd }}$ most corrupt country. In 2004, Nigeria ranked the $3^{\text {rd }}$ most corrupt country and took the $6^{\text {th }}$ sixth position in 2005. It improved to the position of $18^{\text {th }}$ and $32^{\text {nd }}$ in 2006 and 2007 respectively. In 2012 and 2013 , the country took the position of $37^{\text {th }}$ and $33^{\text {rd }}$ corrupt country respectively. In 2014 , Nigeria was still the $38^{\text {th }}$ corrupt country of the world [Uzochukwu, 2016].

Both youths and adults are involved in corruption. The menace of corruption leads students into cheating during examination, scouting for means of getting arbitrary scores beyond their capability, seeking to buy examination questions ahead of the examination, impersonation during examinations, preference of special/miracle centre schools' than schools with integrity to write Secondary School Certificate Examination, using of 'bottom power' to pass examination and involvement in 'runs' of various categories, are affecting the development of the country. Nigeria, being a country endowed with human and material resources, should be among the topmost developed countries of the world. It is worrisome that one of the major setbacks to her development is the act of corruption. The level of corruption among the students of higher institutions is capable of making the institutions fail to produce capable and transparent people needed to enhance development. Kuranche, Twene, Mensah and Arthur [2014] asserted that the moral upbringing of students of tertiary educational institutions is paramount to the sustainability and development of the societies they are being trained for. 
According to them, there is the tendency for the graduates to carry the animosities that results from the corruption experiences they encounter at school to their places of work to the detriment of the societies and the innocent people that their work activities would affect. The fact that the youths of today are the leaders of tomorrow is a pointer to a bleak feature for the country, if the deadly evil practice of corruption among students is not curbed.

According to Priye [htpp//www.gamji.com/article6000/NEWS7987.htm retrieved 23/03/2016], the education sector is as corrupt as the public and private sectors. Therefore, the war on corruption cannot be won without making a determined effort to purge the education sector of the psychosocial beast called corruption. He noted the symbiotic relationship between the educational culture and the political culture a society. What happens to society at large affects the educational sector and whatever happens in the educational sector affects the society at large. Those in the educational sector learn and adopt predominant values generated by society at large and the society at large learns and adopts predominant values generated by the sector [htpp//www.gamji.com/article6000/NEWS7987.htm retrieved 23/03/2016)]

Therefore, the study aims to consider the causes, cases and effects of corruption among the youths of tertiary institutions on development so as to proffer solution. The study will be guided by the following research questions:

1. What are the causes of corruption among students Nigerian of tertiary institutions?

2. What are the manifestations of corruptions among the students of Nigerian tertiary institutions?

3. What are the effects of corruption among students of Nigerian tertiary institutions on development in the country?

\section{LITERATURE REVIEW: THE CONCEPT OF CORRUPTION}

There is no universally accepted definition of corruption. The Malawi Corrupt Practices Act defines corrupt practice as:

a. the offering, giving, receiving, obtaining or soliciting of any advantage to influence the action of any public officer or any other person in the discharge of the duties of that public officer, of official or other person;

b. influence peddling;

c. the extortion of any advantage.

- [Anti-Corruption Bureau, 2013]

The fraudulent means perpetuated by youths of Nigerian tertiary institutions to obtain undue advantage fall within this definition.

Graaf [PAQ SPRING, 2007:46] distinguished the following six groups of theories concerning causes of corruption:

Public choice theory which looks at the individual level. He linked the causal chain to individual making a rational decision that leads to a predetermined outcome. According to him, central to the public choice theory is the individual corrupt official trying to maximize his or her utility. He presented the individual as a rationally calculating person who decides to become corrupt 
when its expected advantages outweighed its expected disadvantages (possible penalty and the chance of being caught).

The bad apple theories, according to him, seek the cause of corruption in the existence of people with faulty (moral) character, the so-called 'bad apples'. He noted a causal chain from bad character to corrupt acts. De Graaf [2007:49] noted the cause of corruption to be rooted in human weakness such as greed. This is a major cause of the 'get rich quick' syndrome among students of tertiary institutions in Nigeria currently.

The third theories, organizational culture theories, traced corruption to certain culture - a certain group culture - that leads to a certain mental culture and that mental state leads to corrupt behaviour [De Graaf, 2007:51]. Emphasis on control of corruption with the mindset of these theories is to influence the culture of the environment concerned.

Clashing moral value theories, according to De Graaf [2007:53], located the causal chain of corruption with certain values and norms in the society that directly influence the values and norms of individuals. He submitted that such values and norms influence the behaviour of individual officials, making them corrupt.

The ethos of public administration theories is concerned with the culture within the public management and society in general. The macro factors, according to De Graaf [2007:56] work through the organization level instead of the individual while the sixth theory, correlation theories, considered all possible levels: individual, organisational and societal.

The first four theories are relevant to understand corrupt practices among students of tertiary institutions in Nigeria. Those who seek to get unmerited certificate or grade do so because of the benefits they intend to get from it. Also, the desire to get rich quick which often prompt students of tertiary institutions to engage in various kinds of betting and internet scam has its source in greed. The degeneration of the culture of hard work among the students of tertiary institutions has led them to employ diverse strategies of 'short-cut' to success. In the same vein, the degeneration of moral values in the society today has eroded the honesty, dignity and integrity needed to live a transparent life.

The former Executive Secretary of National Universities Commission, Okojie, posited that corruption entails unethical practices such as stealing, impropriety, lying, indiscipline, and lawlessness among others [Okoronkwo, 2014]. To him, corruption has its root causes in weak government institutions, poor incentives, lack of transparency, absence of key anti-corruption rules, poverty and the lust for material things.

The political Bureau [cited in Omenka, 2013] identify characteristics of corruption to include the inflation of government contracts in return for kickbacks; frauds and fabrication of accounts in the public service, examination malpractices in our educational institutions including universities; the taking of bribes and perversion of justice among police, the judiciary and other organs for administering justice, and the various heinous crimes against the state in the business and industrial sectors of our economy. These include but are not limited to collusion with multinational companies such as over- invoicing of goods and foreign exchange swindling, hoarding and smuggling,

In their own words, Adebisi, Adebisi and Arogundade [2016] describe academic corruption as all dishonest acts perpetrated in the academic environment by institutional administrators, 
lecturers or teachers, students and other stakeholders in the academic sector or educational institutions which have adverse effect on the academic goals of the institutions. In their definition, academic corruption refers to wrongdoing in the academic environment particularly the tertiary institutions which have pernicious effect on the standard of education. Elaine [2007] identifies different types of corruption. This, according to him, include systemic, sporadic (individual), political (grand), petty, legal and moral corruption. He describes systematic corruption as a situation in which the major institutions and processes of the state are routinely dominated by corrupt individuals and groups, and in which most people have no alternatives to dealing with corrupt officials. While sporadic corruption occurs irregularly and therefore does not threaten the mechanisms of control or the economy as such. It is not crippling, but it can seriously undermine morale and sap the economy of resources. He posited that political corruption is any transaction between private and public sector actors through which collective goods are illegitimately converted into private-regarding payoffs. He also describe petty corruption as bribery in connection with the implementation of existing laws, rules and regulations, which differentiates it from political corruption.

Considering the effects of corruption among students in Nigeria, Memory and Memory [2013] x-rayed corrupt academic practices which, according to them, advertently or inadvertently, has plunged the Nigerian educational system into a tragic situation of endemic examination malpractices and other examination vices. They noted that if the menace of academic corruption is not addressed positively, the educational system will continue to produce halfbaked graduates, poor tertiary education and decline of roles of universities, especially in the area of research and development.

Omenka [2013] linked the causes of corruption to poverty, cultural foundation, and inability of government to sanction corruption, weak institutions of government and lack of exemplary leadership. He believes that corruption is heightened by pervasive and chronic poverty, high level of material deprivation and other structural inequalities. He noted that pressure from extended family is another cause.

Adeola [2015] decried the psychological effects of corrupt practices on the morality of Nigerians, creativity and productivity which are the basis of invention and economic development. He noted that the cankerworm has dampened the morale of many Nigerians to systematically and intelligently employ their innate creative abilities, devalued hard work, weakened diligence, destroyed efficiency, eroded effectiveness, debased obedience and emasculated loyalty.

Transparency International [2015] reiterated the cost of corruption under four major categories; namely political, economic, social and environmental. Politically, corruption constitutes a major obstacle to democracy and the rule of law. It leads to loss of legitimacy of institutions as a result of misuse of office for private advantage.

Also, accountable leadership cannot be developed in a corruption-ridden environment. Economically, Transparency International [2015] noted that corruption depletes national wealth and hinder development by corrupt politicians investing in projects that will benefit their pockets rather than the community. Socially, corruption undermines people's trust in the political system, in its institutions and its leadership. The body also noted the environmental challenges of corruption such as non-implementation of environmental regulations and legislation which further leads to careless exploitation of natural resources and ecological systems. Rather than keep to rules, companies resort to paying bribes in return for 
unrestricted destruction of the environment and its resources [Transparency International, 2015].

Edoghayeobare [2015] summarized the socio-economic effects of corruption as follows: Corruption generally erodes standards to abysmal levels. Quality of goods and services cannot be guaranteed in a corrupt society thereby making Nigeria a savage of dump mentality. Corruption aggravates unemployment and underdevelopment. Corruption engenders mass poverty and thwarts efforts to overcome it. Most infrastructural decay and unsatisfactory provision of amenities can be traced directly or indirectly to corruption. There is a total collapse of power and road networks in the country today due to corrupt attitudes of past leaders. Corruption erodes the ethical base of society, as due diligence, excellence, honesty, merit ..... are discouraged. It breeds all kinds of crimes and vandalism, armed robbery, kidnapping, youth agitations etc.

The above consequences of corruption are the condition of human resources who are expected to build the country. The level of corruption being perpetrated by the youths of tertiary institutions in Nigeria today depicts a gloomy picture of the nation's future since the youths are the leaders of tomorrow.

While discussing the challenges of higher institutions, Aina and Ogundele [2013] revealed that graduates of many institutions cannot live up to expectation in their various areas of specialty after graduation because they do not merit the certificates they are holding. This also has a lot of implications for development. They also noted that Nigerian institutions are not respected outside the country and that Nigerian certificates are mocked outside the country because those who really worked for it are few. The crooked means by which students of tertiary institutions seek to obtain their certificates without actually working for it is a wrong signal for every sphere of development in the country. In the same vein, Badey and Eyichukwu [2016] revealed the production of half-baked graduates as the outcome of dwindling educational standards and ubiquitous corruption hovering all over the Nigerian society. This will hamper development and make the country to remain the puppet of imperialism and depend perpetually on experts from other countries for developmental projects.

In order to curb the short cuts to getting unmerited certificates, Tambawal [2013] posited that government should put a sound educational policy in place that will de-emphasize the supremacy of certificates over skills and professional competence. Ugwuanyi and Eneogu [2013] suggested punishment for any student or lecturer caught in any corrupt act to serve as deterrent to others.

\section{METHODOLOGY}

The study utilized descriptive survey research. The study covers the tertiary institutions in South Western Nigeria [all universities, polytechnics and colleges of education/specialized higher institutions]. The population consists of all students of tertiary institutions in SouthWestern Nigeria. The population sample includes students from two federal and two state owned tertiary institutions. For federal owned institutions, students from University of Ibadan [UI], Ibadan, Oyo State, and Federal Polytechnic, Ado-Ekiti were randomly selected while students from Ekiti State University, Ado-Ekiti, Nigeria and Adekunle Ajasin University, Akungba - Akoko, Ondo State were also selected to represent state-owned institutions. Simple random sampling was used to select students across various Faculties and Departments in the institutions. A total of 300 questionnaires were distributed on 75 copies to each institution. Two hundred and fifty [250], representing $83 \%$ of the questionnaire were recovered. 
Respondents include 138 [55.2\%] males and 112 [48.8] females. They also cut across all Faculties including- Agriculture, Arts, Education, Engineering, Law, Management, Science and Social Sciences. Students from all the levels were also involved, 100 level 86 [34.1\%], 200 level 92 [36.5\%], 300 level 41 [16.3\%] and 400 level 31 [12.3\%].

The questionnaire was validated through thorough scrutiny by other experts in development, statistics and measurement. Data collected were analyzed with the use of frequency counts and simple percentages.

\section{PRESENTATION OF DATA}

The information gathered is presented in tables below showing the frequency and the percentages of responses to corrupt practices and lifestyle of students of tertiary institutions in Nigeria.

Table: 1 Awareness of students on corrupt practices of students in Tertiary Institutions in Nigeria

\begin{tabular}{|c|c|c|c|c|c|}
\hline $\mathrm{S} / \mathrm{N}$ & Awareness & $\begin{array}{l}\text { Frequency } \\
\text { (Yes) }\end{array}$ & $\begin{array}{l}\text { Percentage } \\
(\%)\end{array}$ & $\begin{array}{l}\text { Frequency } \\
\text { (No) }\end{array}$ & $\begin{array}{l}\text { Percentage } \\
(\%)\end{array}$ \\
\hline 1. & $\begin{array}{l}\text { Some students got } \\
\text { fake results }\end{array}$ & 237 & 94.8 & 13 & 5.2 \\
\hline 2. & $\begin{array}{l}\text { Awareness of the } \\
\text { term 'runs' }\end{array}$ & 246 & 98.4 & 4 & 1.6 \\
\hline 3. & $\begin{array}{l}\text { Awareness of } \\
\text { yahoo or yahoo+ } \\
\text { practices }\end{array}$ & 248 & 98.2 & 2 & 0.8 \\
\hline
\end{tabular}

\section{Source: Field Work, 2016}

In table 1, students are highly aware of corrupt practices by students of tertiary institutions in Nigeria. Some of the practices include getting results through dubious means, fake results and yahoo or yahoo+ practice. The fraudulent act of some students getting fake results is acknowledged by 237 respondents representing 94.8\% while 13 respondents representing $5.2 \%$ indicated lack of awareness. Awareness of practicing 'runs' among the students is as high as 246 respondents representing $98.4 \%$ while 4 respondents representing $1.6 \%$ indicated they were unaware. Also, awareness of yahoo or yahoo+ practices of fraudulent means of getting money by some students was supported by almost all respondents, 248 respondents representing $98.2 \%$ while just 2 respondents representing $0.8 \%$ indicated they were unaware. From the above, it is no more a secret that corrupt practices are very rampart among students of tertiary institutions in Nigeria.

Table: 2 Causes of corrupt practices among students of Tertiary institutions in Nigeria

\begin{tabular}{|l|l|l|l|l|l|}
\hline S/N & Causes & $\begin{array}{l}\text { Frequency } \\
(\text { Yes })\end{array}$ & $\begin{array}{l}\text { Percentage } \\
(\%)\end{array}$ & $\begin{array}{l}\text { Frequency } \\
(\text { No) }\end{array}$ & $\begin{array}{l}\text { Percentage } \\
(\%)\end{array}$ \\
\hline 1. & Laziness & 224 & 89.6 & 26 & 10.4 \\
\hline 2. & Self-indulgence & 213 & 85.2 & 37 & 14.8 \\
\hline 3. & Peer influence & 213 & 85.2 & 37 & 14.8 \\
\hline 4. & $\begin{array}{l}\text { Erosion of the } \\
\text { Culture of hard } \\
\text { work }\end{array}$ & $\begin{array}{l}\text { Greed and } \\
\text { desire to get } \\
\text { rich quick }\end{array}$ & 92.8 & 18 & 7.2 \\
\hline 5. & & 100 & 0 & 0 \\
\hline
\end{tabular}

Source: Field Work, 2016 
Table 2 above shows that laziness among the students, self-indulgence, disappearance of culture of hard work and the get rich quick syndrome, coupled with greed among the youths of tertiary institutions are among the causes of corrupt practices that has become rampart among the students. High percentages of responses are in the affirmative of these causes. 224 [89.6\%] of the respondents believed that laziness made students seek short-cuts to success while 26 respondents [10.4\%] had contrary opinion. While 213 [85.2\%] of the respondents opined that self-indulgence and disappearance of the culture of hard work are other causes of corrupt practices among students of tertiary institutions in Nigeria, 37 respondents [14.8\%] were of different opinion. All the respondents 250 [100\%] supported that greed and get rich quick syndrome was a major cause of corrupt practices among students of tertiary institutions in Nigeria.

Table: 3 Nature of Corrupt Practices among Students of Tertiary Institutions in Nigeria

\begin{tabular}{|c|c|c|c|c|c|}
\hline $\mathrm{S} / \mathrm{N}$ & Practices & $\begin{array}{l}\text { Frequency } \\
\text { [Yes] }\end{array}$ & $\begin{array}{l}\text { Percentage } \\
{[\%]}\end{array}$ & $\begin{array}{l}\text { Frequency } \\
\text { [No] }\end{array}$ & $\begin{array}{l}\text { Percentage } \\
{[\%]}\end{array}$ \\
\hline 1. & Fake Results & 237 & 94.8 & 13 & 5.2 \\
\hline 2. & 'Runs' & 246 & 98.4 & 4 & 1.6 \\
\hline 3. & $\begin{array}{l}\text { The use of } \\
\text { 'bottom power' } \\
\text { to get undue } \\
\text { scores/grades }\end{array}$ & 224 & 89.6 & 26 & 10.4 \\
\hline 4. & $\begin{array}{l}\text { Collection of } \\
\text { more than } \\
\text { institution's } \\
\text { approved } \\
\text { school fees } \\
\text { from parents }\end{array}$ & 195 & 78 & 55 & 22 \\
\hline 5. & $\begin{array}{ll}\text { Involvement } & \text { in } \\
\text { yahoo } & \text { or } \\
\text { yahoo+ } & \\
\text { practices } & \\
\end{array}$ & 248 & 98.2 & 2 & 0.8 \\
\hline 6. & Internet Scam & 241 & 96.4 & 9 & 3.6 \\
\hline 7. & Betting & 249 & 99.6 & 1 & 0.4 \\
\hline
\end{tabular}

Source: Field Work, 2016

Table 3 above shows some of the corrupt practices of students in tertiary institutions in Nigeria. From the response, some of such students have the habit of using crooked means to get the results that are not gotten by merit but through dubious means. Two hundred and thirty-seven [237] representing $94.8 \%$ of the respondents were of the opinion that some students used to obtain fake results while 13 [5.2\%] were of contrary opinion. Most of the respondents, 246 [98.4\%] reveal that such corrupt students do engage in 'runs' (payment to get scores, replacing examination scripts with ready-made answers scripts etc.) while only 4 [representing 1.6\%] of the respondents were of a different opinion. Substantial number of the respondents, 224 [89.6\%] opined that the use of 'bottom power' to get high scores is rampart among corrupt students of tertiary institutions while 26 [10.4\%] do not agree that practices exist. A reasonable number of the respondents, 195 [78\%] affirmed that some of the corrupt students exhort their parents by inflating the school fees they collect from them while 55 [22\%] were of a different opinion. Almost all, 248 [98.2\%] believed in the reality of the practice of yahoo+ by corrupt students of tertiary institutions, while only two [2] [0.8\%] responded 'No'. Involvement in internet scam is believed to be among the corrupt practices of some students of tertiary institutions in Nigeria. 241 [96.45] of the respondents affirmed the existence of such practice while only 8 [3.6\%] were of contrary opinion. Also, almost all, [249 or $99.6 \%$ ] of the respondents opined that 'betting' was among the corrupt practices of students 
in tertiary institutions in Nigeria. Only 1 [0.4\%] was of a different opinion. The responses above revealed that corrupt practices are rampart among the students of tertiary institutions in Nigeria and this has serious implications for national development.

Table: 4 Lifestyle of students with corrupt practices in Tertiary Institutions in Nigeria

\begin{tabular}{|l|l|l|l|l|l|}
\hline S/N & Lifestyle & $\begin{array}{l}\text { Frequency } \\
{[\text { Yes }]}\end{array}$ & $\begin{array}{l}\text { Percentage } \\
{[\%]}\end{array}$ & $\begin{array}{l}\text { Frequency } \\
(\text { No) }\end{array}$ & $\begin{array}{l}\text { Percentage } \\
(\%)\end{array}$ \\
\hline 1. & $\begin{array}{l}\text { Use of exotic } \\
\text { cars }\end{array}$ & 82.4 & 44 & 17.6 \\
\hline 2. & $\begin{array}{l}\text { Attending } \\
\text { Lectures }\end{array}$ & 113 & 45.2 & 137 & 54.8 \\
\hline 3 & $\begin{array}{l}\text { Living above } \\
\text { their means }\end{array}$ & 202 & 80.8 & 48 & 19.2 \\
\hline 4. & $\begin{array}{l}\text { They spend } \\
\text { more time on } \\
\text { internet than } \\
\text { on their studies }\end{array}$ & $\begin{array}{l}\text { They live } \\
\text { flamboyant } \\
\text { lives }\end{array}$ & 98.8 & 3 & 1.2 \\
\hline 5. & & 96.8 & 8 & 3.2 \\
\hline
\end{tabular}

Source: Field Work, 2016

The above table 4 depicts the lifestyle of corrupt students of tertiary institutions in Nigeria. Such students are fond of using exotic cars, even though they come from average and poor families. Two hundred and six [206] representing $82.4 \%$ of the respondents were of the above opinion while 44 (17.6\%) were not. Also, 113 [45.2\%] of our respondents believed that such corrupt students rarely attend lectures while 137 [54.8\%] were of a contrary opinion. It was observed by 247 [98.8\%] of our correspondents that students with such corrupt practices spend more time busy on the internet than they spend on their academics, while only 3 [1.2\%] were of a different opinion. Also, 242 [96.8\%] of our respondents believed that students with corrupt practices do live flamboyant lifestyles, only 8 [3.2\%] of the respondents did not share this opinion.

\section{DISCUSSION OF FINDINGS}

Findings from our respondents in table 1 above show a high rate of awareness of corrupt practices among students of tertiary institutions in Nigeria. It is not a hidden case as many students are not ignorant of the evil. Some of the causes of corrupt practices identified by the respondents include laziness, self-indulgence, peer influence, the eroding culture of hard work, greed and the get- rich- quick syndrome. In the opinion of Adebisi, Adebisi and Arogundade (accessed 2016), primordial sentiment, poverty, desire to get rich quick, cultural values among others were seen as the causes of such practices among students. Investigation on the nature of corrupt practices reveals that some students do obtain fake results through fraudulent means, some engage in 'runs' [payments of money to get scores or replace examination scripts with 'ready- made' answered scripts]. Besides, on the part of the ladies, the use of 'bottom power' [giving out their bodies for sex to male lecturers as exchange for enhanced scores] is also recognized as another corrupt means to get the grade they are not worth. The grade of certificate gotten by students in that category will not be a true reflection of their abilities.

The practice of yahoo or yahoo+, which involves duping innocent people of their hard-earned money, is also revealed to be rampart among students of tertiary institutions in Nigeria. The get-rich- quick syndrome among students has led some of them to the unholy practice of reaping where they did not sow. In line with the yahoo or yahoo+ is the practice of internet scam. This involves deceiving people through announcement of fake intended 
conferences/workshops, business deals etc. with the primary aim of asking their victims to pay certain amounts of money when there is no plan for such a deal. In line with this, Tade and Aliyu [2011: 865-867] identified different strategies being employed by the yahoo boys which include placing false job advertisement in newspapers to defraud job seekers, sending fraudulent messages to deceive subscribers of certain communication networks, false messages about winning cash prizes, online dating, money transfer, international transfer, etc.

Besides, the practice of various types of betting has been identified among students of tertiary institutions in Nigeria. Respondents identified baby betting, sports betting, 1960 betting, sure bet, Baba Ijebu, 360 betting, naija bet, Ajah 4, etc. These are forms of modernized pool designed for getting rich quickly, students involve in these for quick turn over of profit where they did not sow. In line with this, Oboh [2015] in his findings on prevalence and determinants of gambling behaviours among undergraduates' students, using Federal University of Technology, Oye - Ekiti, as a case study, discovered that many students who engage in such acts practice it weekly. He also further revealed that poor academic performance such as D or below is associated with gambling.

The findings on the lifestyle of students who engage in corrupt practices especially the internet scam and yahoo or yahoo+ shows that they live flamboyant lives. Respondents noted that students in this category use flashy cars, though they are from average and poor family backgrounds. They live expensive lifestyles, carry ladies about, attend drinking joints and hotels and hardly have time for their academics which is the primary purpose of coming to school. It was also revealed that such students spend more time on the internet than they do to attend to their lectures; some of them hardly attend lectures. They also believe they can buy their way through to pass their courses. In line with this, Tade and Aliyu [2011:870] opined "Yahoo-boys enjoys a status of big boys and are socially recognized among friends, and lecturers. Their flamboyant lifestyle entices others to desire belonging to the clique"

\section{Implications for Development}

The above findings on corruption among students of tertiary institutions in Nigeria have implications for the socio-economic and political development of the country. Socially, it undermines the national image of the country. Nigeria has been rated high on the global corruption index by many findings of Transparency International. Nigerians outside the country are treated with the impression of corruption. According to Edoghayeobare [2015], a corrupt-ridden country stinks among the comity of nations. Fraudulent practices of some students of tertiary institutions in Nigeria constitute a collapse to the value of dignity, knowledge, integrity and seriousness [Benjamin, 2014:9] which has been the potential of increasing the crime rate in the Country. Ogunfunmilakin [2015:37] opined that corruption will propagate the culture of corruption which the youths now see as beneficial and as a result jettison integrity and honesty and uphold injustice, bribery, killing and other vices that are detrimental to their career, social, personal and religious goals. Besides, their fraudulent deals make them fall victims of evils and calamities which some even pass to their generations. Economically, investors may be scared for fear of dubious dealings. Since the youths are the leaders of tomorrow, diversion of developmental funds to private purse will be high since they are used to reaping where did not sow. Production of half-baked graduates, who prey on, rather than impact the economy with effective service, is another attendant effects of 'shortcut' to getting certificates through dubious practices.

Politically, corrupt practices will characterize the political terrain because of the get -richquick syndrome. Motivation for political contestants will be personal interest for quick wealth. 
This has been the primary motive for 'do or die' politics in the country. According to Ogunfunmilakin [2015:38]:

Society where her educated citizens trade their personal human value for daily sustenance, these affect their political value and orientation. That is why educated citizen from Nigeria and other developing countries sees political office as a remedy of finding solutions to the problems of poverty affecting their family and jettisoned the ideal philosophy of gaining power in order to be a servant leader. In essence, when citizens with wrong political orientation stir the affair of the state, they entrenched the spirit of corruption and corrupt practices in all sectors of society as such, making the process a continuous and cyclical in nature.

In situations like those described above, development will elude the state because funds meant for developmental projects will be diverted to private purse. Personal interest, in most cases will be set above state interest while the level of poverty and underdevelopment will be deepened. Such leaders cannot be accountable to the people.

\section{RECOMMENDATIONS}

Proper orientation should be given to students at resumption on the danger of the evil of peer influence on campuses.

Lectures and seminars should be organized to enlighten students of the evils of corrupt practices.

Institutions of higher learning should hammer the rules and regulations on the ethics of learning. Serious sanctions should be put in place by various institutions against erring students.

Security personnel should be at alert to arrest students with questionable acts so that such can be brought to book to serve as deterrence to others.

Parents and guardians should check on their wards at school unannounced to know the type of life they are living.

Government should come up with a kind of policy to acknowledge merit above certificates in the process of employment.

\section{References}

Adebisi, P. A., Adebisi, O. S. and Arogundade, K. K. (2016); “Academic Corruption and the Challenge of Unemployable Graduates in Nigeria: Implications for Enterpreneurship Development and Economic Growth", Journal of Commerce, Vol 1 No 4

Adeola, G. L. (2015); “The Deepening Culture of Corruption in Nigerian Society: Implications for Governance, Development and Stability", American International Journal of Research in Humanity, Arts and Social Sciences, htpp://www.iasir.net retrieved 23/03/2016

Aina J. K.and Ogundele, A. G. (2013); Science and Technical Education: A Panacea for Tertiary Institutions' Challenges, $1^{\text {st }}$ International Conference on Science and Education Development Potentials, Swan International Hotel, Akure, Ondo State, Nigeria, October, $8^{\text {th }}-9$ th

Anti-Corruption Bureau, Malawi (2013), “Definition of Corruption”, http://www.acbmw.com/?page_id=239 retrieved $31 / 03 / 2016$

Badey, D. and Eyichukwu, K. (2016); Dwindling Educational Standards and Ubiquitous Corruption: Causes, Implications and Options, Donnish Journals of Educational Research and Reviews, Vol 3(2) pp 009-011 August 
Benjamen, S. A. (2014); Federalism, Politics and Corruption in Nigeria: Implications for Higher Education, Developing Country Studies, Vol 4, No 24

Elaine, B. (2007); Definitons and Types of Corruption" http://elaine.ie/2009/07/31/definitions-and-types-ofcorruption/ retrieved 31/03/2016

Edoghayeobare, A. M. (2015); Corruption, the Bane of Nigerian Socio-Economic Development, The Nigerian Observer, October 7, http://www.nigerianobservernews.com/2015/10/corruption-the-bane-of-nigerian-socio-economicdevelopment/ retrieved 19/09/2016

Kuranche, A., Twene, C., Mensah, M. K. and Arthur, C. (2014); "The Perceived Corrupt Practices of Academics: What Conditions Promote Them?” , Academic Journal of Interdisciplinary Studies, Vol 3 No 1, March

Memory, Q. S. and Memory, D. (2013); “Corrupt Academic Practices: A Tragedy in Nigerian Educational System”, Journal of Education and Practice, Vol 4, No 27

Oboh, V.C. (2015); Prevalence and Determinants of Gambling Behaviours Among Undergraduate Students, (A Case Study of Federal University, Oye - Ekiti), A Research Projevt Submitted to the Department of Sociology, Faculty of Social Science and Humanity, Federal University of Oye -Ekiti, Ekiti State

Ogunfunmilakin, I. (2015); Socio - Economic Implication of Corruption and Corrupt Practice on Nigerian Educational System, Developing Country Studies, Vol 5, No 16

Okoronkwo, C. (2014); “Okojie Identifies Causes of Corruption in Nigerian Universities”, NANS, December 17 http://nannewsnigeria.com/okojie-identifies-causes-corruption-nigerian-universities retrieved 31/03/2016

Omenka, I. J. (2013); The Effects of Corruption on Development in Nigeria, IOSR Journal of Humanities and Social Science (IOSR-JHSS) Volume 15, Issue 6(Sep. Oct.). pp 39-44

PAQ SPRING, (2007); Causes of Corruption: Towards a Contextual Theory of Corruption, http:/unpan1.un.org/intradoc/groups/public/documents/un-dpadm/unpan049603.pdf retrieved 17/10/2016

Priye, S. T. (accessed, 2016); "The Corrosive Effects of Corruption on Nigerian Educational System", Htpp//www.gamji.com/article6000/NEWS7987.htm retrieved 23/03/2016

Tade 0. and Aliyu, I. (2011); Social Organisation of Internet Fraud Among Universities Undergraduates in Nigeria, International Journal of Cyber Criminology, July - December, Vol 5 (2): 860 - 875

Tambuwal, M. U. (2013); Examination Practices: Causes, Effects and Solutions, Paper Presented at the Stakeholders Forum on Raising Integrity in the Conduct of Examinations in Nigerian Educational System. Thursday $7^{\text {th }}$ February, http://www.academia.edu/3819778/EXAMINATION_MALPRACTICES_CAUSES_EFFECTS_AND_SOLUTIONS retrieved 20/09/2016

Transparent International (2015); What is Corruption", http://www.transparency.org/what-is-corruption/ retrieved $30 / 03 / 2016$

Ugwuanyi, B. E. and Eneogu, D. N. (2013); Corruption as the Bane of Quality Education in Nigeria, International Journal of Research in Arts and Social Sciences, Vol 6

Uzochukwu, M. (2016); “Corruption in Nigeria: Review, Causes, Effects and Solutions”, Hubpapes, February 18. 